Aysaule AKHMEDIEVA, Master's student of Karaganda University of Kazpotrebsoyuz, aisaule.abdulova@nu.edu.kz

Aliya ABDIKARIMOVA, Associate Professor of the Department of Economics and Entrepreneurship of the Karaganda University of Kazpotrebsoyuz, aliyata@mail.ru

\title{
CONCEPTS OF SUSTAINABLE DEVELOPMENT IN THE ACTIVITIES OF KAZAKHSTANI COMPANIES
}

The article considers the content of the concept of sustainable development, gives the main directions of sustainable development adopted in the world practice and reveals the features of the application of the practice of sustainable development in the group of companies «Kazzinc»

Айсәуле АХМЕДИЕВА, Қазтұтынуодагы Қараганды университетінің магистранты, aisaule.abdulova@nu.edu.kz

Әлия АБДИКАРИМОВА, Қазтұтынуодавы Қараванды университетінің экономика және кәсіпкерлік кафедрасының доиенті, aliyata@mail.ru

\section{ҚАЗАҚСТАНДЫҚ КОМПАНИЯЛАР ҚЫЗМЕТІНДЕГІ ТҰРАҚТЫ ДАМУ ТҰЖЫРЫМДАМАСЫ}

Мақалада тұрақты даму ұғымының мазмұны қарастырылады, әлемдік тәжірибеде қабылданған орнықты дамудың негізгі бағыттары Берілген және "Қазмырыш" компаниялар тобында орнықты даму практикасын қолдану ерекшеліктері ашылған.

Айсауле АХМЕДИЕВА, магистрант Карагандинского университета Казпотребсоюза, aisaule.abdulova@nu.edu.kz

Алия АБДИКАРИМОВА, доџент кафедры экономики и предпринимательства Карагандинского университета Казпотребсоюза, aliyata@mail.ru

\section{КОНЦЕПЦИИ УСТОЙЧИВОГО РАЗВИТИЯ В ДЕЯТЕЛЬНОСТИ КАЗАХСТАНСКИХ КОМПАНИЙ}

В статье рассматривается содержание понятия устойчивое развитие, даны основные направления устойчивого развития принятые в мировой практике и раскрыты особенности применения практики устойчивого развития в группе компаний “Казцинк

The concept of sustainable development at the macroeconomic level was developed in the 70 s of the 20th century, when the understanding of the need to take into account the interests of the life of the next generations, the greening of scientific knowledge, became most relevant. The concept of sustainable development involves ensuring the development of a society that unites and ensures the unity of 3 areas: economic, environmental and social. This means that profit maximization and economic growth are ensured by saving technologies, greening production, and ensuring effective social security conditions for the population.

In order to ensure sustainable development, a number of resolutions have been adopted that define the main goals that society will achieve by achieving sustainable development (Figure 1) 



Fight against changes climate change

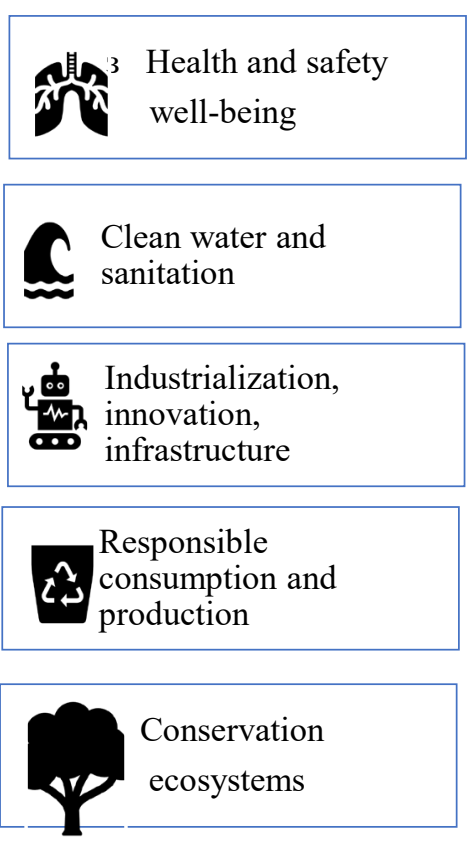

Conservation

ecosystems
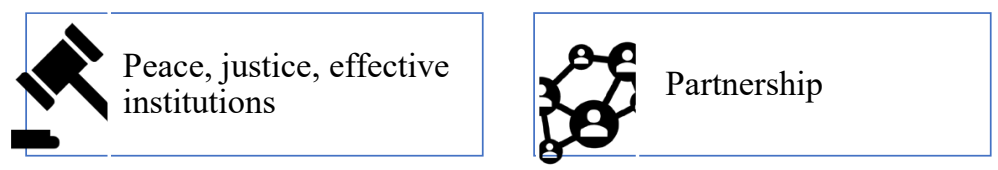

Figure 1 Directions that ensure the sustainable development of the society

Each of these goals is focused on solving a task to ensure sustainable development.

If this is generally relevant to the macro level, then similar tasks are set at the firm level[1,2].

Such principles are currently adhered to by the Kazzinc Group of companies.

A vertically integrated polymetallic company, the largest producer in Kazakhstan, which accounts for a significant part of the production of zinccontaining ores and the production of zinc metal. Kazzinc is also known for its significant production of precious metals, copper and lead

The presented mission of the company is to create sustainable value for our owners, employees, partners and society through the progressive development and sustainable use of natural resources and energy sources with minimal risk to society, the environment and human health.

Company strategy

Minimize the impact on humans and the environment: continue to implement best practices and, as new technologies develop, apply them in order to reduce the harmful effects on humans and reduce the impact of production on the environment, as well as eliminate the likelihood of accidents and occupational diseases.

Increase profitability: continuously improve production and management processes through the introduction of new technologies, methods to increase productivity and energy efficiency, and reduce production costs in fields and production facilities.

Table 1 - The main indicators of Kazzinc Group of companies

\begin{tabular}{|l|l|l|}
\hline & 2020 & 2019 \\
\hline Revenue/ Zink assets & 3031 & 2906 \\
\hline Capital expenditure & 394 & 445 \\
\hline Production from own sources & $1,170.4$ & $1,077.5$ \\
\hline Production from own sources - Zinc assets & 167.5 & 172.5 \\
\hline Lead metal & 25.6 & 31.6 \\
\hline
\end{tabular}

Kazzinc Own sourced zinc production of 167,500 tonnes was 5,000 tonnes $(3 \%)$ lower than
2019. Own sourced lead production of 25,600 tonnes was 8,800 tonnes $(26 \%)$ lower than 2019 , reflecting 
maintenance on the lead smelter and mining from the Ushkatyn mine in the base period, which has now ceased. Own sourced copper production of 37,000 tonnes was 7,000 tonnes (16\%) lower than 2019 due to expected lower grades at Maleevsky mine, and maintenance at the Ridder-Sokolny concentrator. Own sourced gold production of 659,000 ounces was 25,000 ounces (4\%) higher than 2019, mainly reflecting higher grades and recoveries at Vasilkovsky.

\section{0 developments and overview of principal risks and uncertainties}

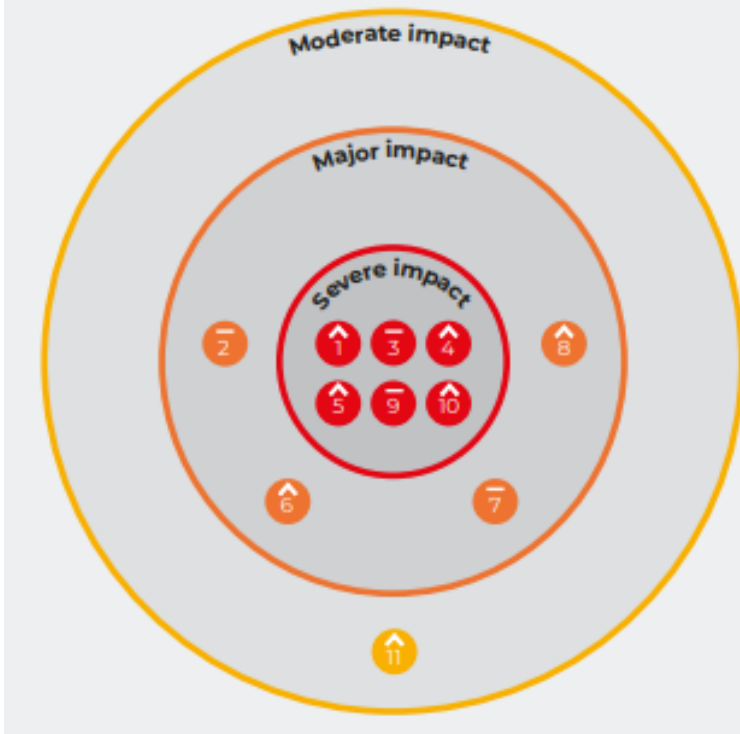

KEY

External risks

1 - Supply, demand and prices of commodities

2 Currency exchange rates

3 - Ceopolitical, permits and licences to operate

4. Laws and enforcement

5 - Liquidity

Business risks

6 Counterparty credit and performance

7 - Operating

8 - Cyber

Sustainability risks

9 - Health, Safety, Environment

10 - Climate change

11 - Community relations and human rights

Risk impact

- Moderate - Major - Severe

Risk probability change in 2020 v 2019

A Increase - Stable 
Тем не менее, даже несмотря на предпринимаемые усилия в группе компаний Казцинк, очень высокий риск в области обеспечения экологической безопасности и сохранения здоровья. На рисунке 2 отражены данные об основных рисках и в области устойчивого развития.

Climate change may increase physical risks to assets and related infrastructure, largely driven from extreme weather events and water related risks such as flooding or water scarcity. There has been a significant increase in litigation (including class actions), in which climate change and its impacts are a contributing or key consideration, including administrative law cases, tortious cases and claims brought by investors. In particular, a number of lawsuits have been brought against companies with fossil fuel operations in various jurisdictions seeking damages related to climate change.

Company continuously monitor and report emissions, and use this data in managing operational carbon footprint, as well as the development and tracking of our targets. To understand better and plan for the effects of climate change on business, company have a framework for identifying, understanding, quantifying and, ultimately, managing climate-related challenges and opportunities facing our portfolio:

- Government policy: company takes an active and constructive role in public policy development of carbon and energy issues, both directly and through our industry organisations.

- Lobbying activities: company acknowledges IIGCC Investor Expectations on Corporate Climate Lobbying and recognise the importance of ensuring that our membership in relevant trade associations does not undermine our support for the Paris Agreement and its Goals

- Carbon pricing: we operate successfully in multiple jurisdictions that have direct and indirect carbon pricing or regulation. We have identified some parts of our business that would likely experience financial stress in a high carbon price environment. However, our conclusion is that our business overall remains resilient. We consider local regulation and carbon price sensitivities as part of our ongoing business planning for existing industrial assets, new investments and as part of our marketing activities. We are working with relevant industry organisations on developing lifecycle analysis to calculate our commodities' carbon footprint

- Energy costs: company considers energy costs and our carbon footprint in our annual business planning process.

- Physical impacts: company tracks changing weather conditions and amend operating processes as appropriate, as well as incorporate climate risk into our design and planning. We regularly review the integrity of our assets, including tailings storage facilities, against the potential impact of extreme weather events.

- Access to capital: company regularly reviews our banks' climate change-related policies and evolving applicable restrictions, if any. Through maintaining a strong relationship with our lenders, we continue to have a broad range of sources from which to access funds.

- Permitting risk: company engages with a broad range of stakeholders on diverse topics including climate change and related areas of concern. Our engagement with our local communities and those directly affected by our operations is transparent and honest. Where we identify differing opinions, we look for opportunities to find constructive solutions.

- Product demand: company responds to regulatory and technology developments. There are nearterm opportunities in positively repositioning many of our products that enable the decarbonisation transition.

\section{References:}

1. Merzliakov Viacheslav Fedorovich, Vinokurov Andrei Aleksandrovich Razrabotka modeli strategii ustoichivogo razvitiia firmy // Rossiiskoe predprinimatelstvo. 2013. №23 (245). URL: https://cyberleninka.ru/article/n/razrabotka-modeli-strategii-ustoychivogo-razvitiya-firmy (data obrashcheniia: 02.04.2021).

2. Zhurova Liudmila Ivanovna, Toporkov Andrei Mikhailovich Analiz podkhodov k ustoichivomu razvitiiu integrirovannykh korporativnykh sistem // Vestnik VUiT. 2015. №1 (33). URL: https://cyberleninka.ru/article/n/analiz-podhodov-k-ustoychivomu-razvitiyu-integrirovan-nyhkorporativnyh-sistem (data obrashcheniia: 02.04.2021). 